\title{
Application of Electrical Geophysical Method in Site Selection for Viable Area for Agricultural Practices: A Case Study of Ukpenu-Ibhiese and Iruekpen Edo State-Nigeria
}

\author{
Aigbedion Isaac $^{{ }^{*}}$ and Salufu Samuel ${ }^{1}$ \\ ${ }^{1}$ Geophysics Physics Department, Ambrose Alli University, Ekpoma, Nigeria.
}

Authors' contributions

This work was carried out in collaboration among all authors. Author Al designed the study, performed the statistical analysis, wrote the protocol, and wrote the first draft of the manuscript. Author SS managed the analyses of the study. Authors AI and SS managed the literature searches. All authors read and approved the final manuscript.

Article Information

DOI: 10.9734/AJGR/2021/v4i230130

Editor(s):

(1) Dr. Nadhir Al-Ansari, Lulea University of Technology, Sweden. (2) Dr. Xu Chong, China Earthquake Administration, China. (3) Dr. Hani Rezgallah Al-Hamed Al-Amoush, Al al-Bayt University, Jordan. Reviewers: (1) Irfan Ahmad Afip, Universiti Malaya, Malaysia.

(2) P. Samatha Chowdary, R. V. R. and J. C. College of Engineering, India. Complete Peer review History: http://www.sdiarticle4.com/review-history/67523

Original Research Article

Received 27 February 2021

Accepted 02 May 2021

Published 17 May 2021

\begin{abstract}
Electrical geophysical method was applied, to select viable area with essential soil nutrients for plant's growth. Conventional soil test analysis was carried out for the purpose of confirmation. A case study was done at Ukpenu-Ibhiese and Iruekpen in Ekpoma. The result of the electrical resistivity geophysical method showed that southwest and northwest of the area has resistivity values that ranged between $80 \Omega \mathrm{m}$ to $170 \Omega \mathrm{m}$ while the remaining part of the area has values higher than $170 \Omega \mathrm{m}$, ranged from $580 \Omega \mathrm{m}$ to $950 \Omega \mathrm{m}$. Values of organic matter, Nitrogen, Phosphorus, and Potassium, obtained from the soil test in area with $80 \Omega \mathrm{m}$ to $170 \Omega \mathrm{m}$ indicated good proportion of essential soil nutrients for plant growth while area with resistivity values that ranged from $580 \Omega \mathrm{m}$ to $950 \Omega \mathrm{m}$ was deficient in essential soil nutrients for plant growth. The results further proved that soil electrical physical properties thus detected and mapped can be used as a proxy of physical, chemical, and biological features relevant for the appropriate site selection and soils management, based on their resistivity behavior, spatial variability, and time dynamics in the area of study.
\end{abstract}


Keywords: Soil resistivity; vertical electrical sounding; agro-geophysics; essential soil nutrients.

\section{INTRODUCTION}

Geophysics is the application of physical quantity measurement techniques to provide information on conditions or features beneath the Earth's surface [1]. Geophysics provides a set of robust, cost-effective, and completely noninvasive or minimally invasive technologies for near-surface investigations able to estimate the physical properties of the shallow layers of soil and subsoil.

Agro geophysics is a pioneering technique in precision agriculture. It has not yet reached its full potential, and it is continuously being developed. The role of geophysical methods in agriculture is becoming more important in Nigeria and all over the world. Geophysical methods have been increasingly popular for shallow and environmental studies worldwide. In particular an electrical geophysical method is helpful in soil investigation which focuses on an interval from the ground surface down to a depth of 2 meters [2]. The three geophysical methods suitable for agricultural purposes are resistivity, electromagnetic induction and groundpenetrating radar. Geophysical methods not traditionally employed in the past for agricultural purposes will find significant use in the future $[3,4]$. Soil structure is defined as the spatial arrangement of soil constituents (minerals and organic matter) and void of soil [5] . Soil electrical conductivity (EC) is a measure of the amount of salts in soil (salinity of soil). It is an important indicator of soil health. It affects crop yields, crop suitability, plant nutrient availability, and activity of soil microorganisms which influence key soil processes including the emission of greenhouse gases such as nitrogen oxides, methane, and carbon dioxide [6].

There was some agricultural research activity in the1930s and 1940s related to soil moisture measurement with resistivity methods [7,8,9]; but for the most part, the application of geophysical methods to agriculture did not gain momentum until the 1960s, and to a greater extent in the 1970 s, with the use of resistivity methods for soil salinity assessment [7].

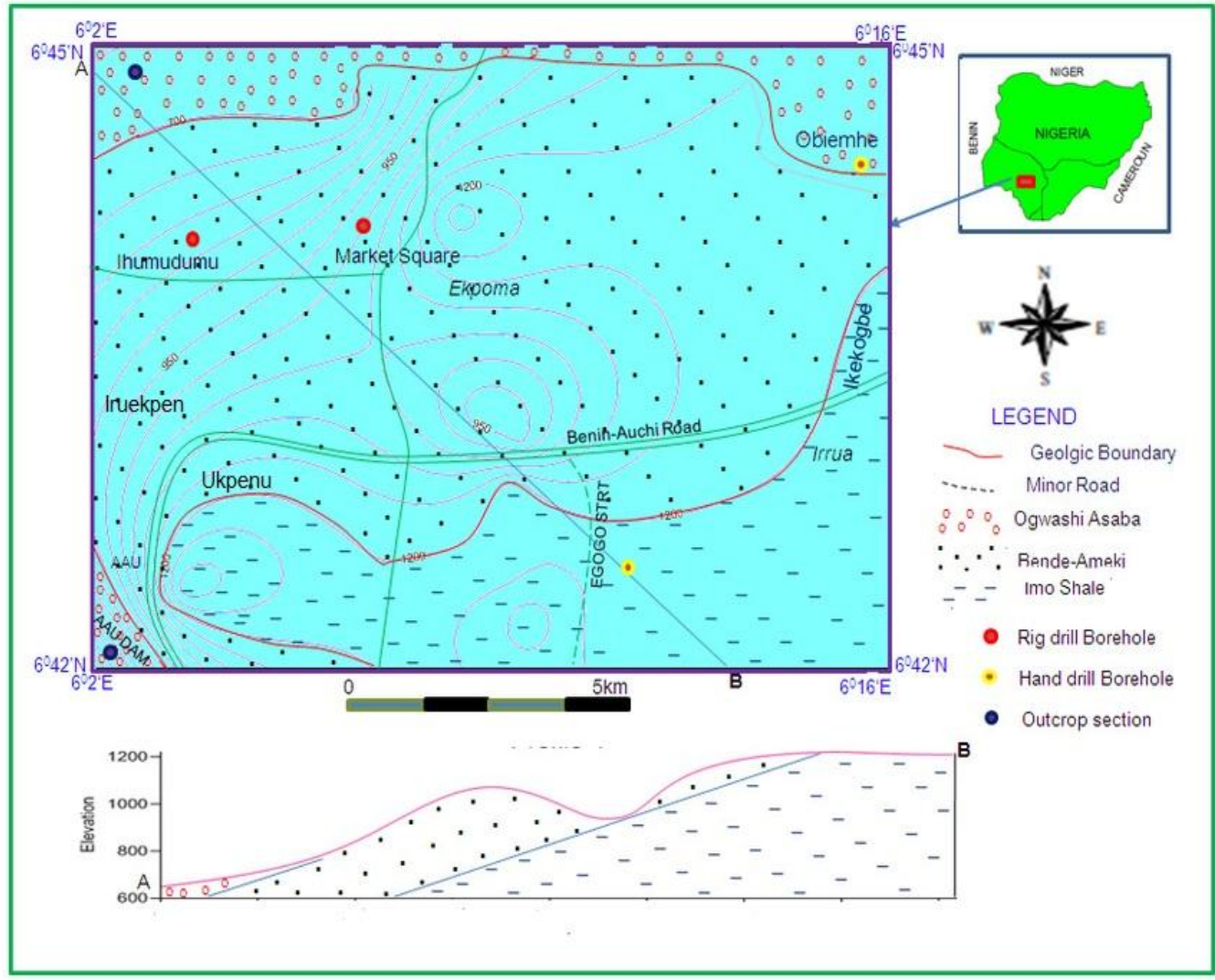

Fig. 1. Geological map of the study area (Modified after Salufu and Ujuanbi [12]) 
Resistivity methods used in this study measure the electrical resistivity, or its inverse, electrical conductivity, for a bulk volume of soil directly beneath the surface. Resistivity methods basically gather data on the subsurface electric field produced by the artificial application of electric current into the ground. With the conventional resistivity method, an electrical current is supplied between two metal electrode stakes partially inserted at the ground surface, while voltage is concurrently measured between a separate pair of metal electrode stakes also inserted at the surface. The current, voltage, electrode spacing, and electrode configuration are then used to calculate a bulk soil electrical resistivity (or conductivity) value using software. Electrical conductivity (ECa) or its inverse resistivity (ER) is one of the most utilized variable to indirectly assess soil spatial variability in agricultural fields $[10,11]$.The techniques commonly used to measure the ECa variation within the root zone at field scale are essentially two: Electrical resistivity (ER) and Electromagnetic induction (EMI).

This paper intend to show that electrical geophysical methods when integrated with soil test and textural analysis can assist in farm planning and can provide valuable information for agriculture purposes about oil fertility, water table and soil characterization. The study further intend to identify suitable crop(s) in the study area.

\section{GEOLOGY OF THE STUDY AREA}

The area between Ukpenu-Ibhiese and Iruekpen has high topography ranging from $910 \mathrm{ft}$ to $1185 \mathrm{ft}$ forming a general flat terrain that forms a plateau. The area falls within the Edo StateNigeria arm of Anambra Basin. It is underlain by Okwashi-Asaba Formation of Nigeria. The formation lithology ranges from lateritic sandstone, sandstone, mudstone, siltstone and clayey sandstone.

\section{MATERIALS AND METHODS}

A geophysical electrical investigation was performed by carrying out six Vertical Electrical Sounding (VES) in the study area (Fig. 2). The geophysical electrical method was integrated with soil test and textural analysis in the area of study. Soil testing was carried out by collecting five representative soil samples across the study area as shown in Fig. 2, according to the standard in the laboratory. Point of samples collection was geo-referenced. Laboratory analysis of soil test and textural analysis (soil particle size analysis) of soil were done and results interpreted. Geophysical study of the subsurface soil was done to determine the load bearing strength of the soil, in-situ nature of the soil and depth to water table across the study area.

The Schlumberger configuration was adopted due to its reliability in depth sounding and strength of geology material determination. The Schlumberger vertical electrical sounding was carried out along the profile using SAS 1000 ABEM Terameter. The maximum electrodes $(A B / 2)$ spread ranged from $200 \mathrm{~m}$ to $390 \mathrm{~m}$ in the study area. The electrode movements on the current electrodes $\mathrm{C} 1, \mathrm{C} 2$ are moved outward symmetrically, keeping $\mathrm{P}_{1}, \mathrm{P}_{2}$ fixed at the centre. With this procedure often called electric drilling, the property of the subsurface was explored to determine the load carrying strength capacity of the soil, in-situ soil nature, and water table across the study area.

In this way, it is possible to calculate the apparent resistivity $(\rho)$ :

$$
\rho=\frac{\Delta V}{I}
$$

\section{RESULTS AND DISCUSSION}

The apparent resistivity result for the six VES conducted in the study area is presented in Table 1. The inversion models for the six resistivity result are given in Fig. 3 to Fig. 8. The result showed that VES 1, VES 3, VES 4, and VES 6 from topsoil to depth of about $2 \mathrm{~m}$ ranged from 80 $\Omega \mathrm{m}$ to $170 \Omega \mathrm{m}$ as shown in Fig. 3, 5, 6 and 8 . These values indicate good content of organic matter good enough for crop nourishment while VES 2 and VES 5 have values that ranged from $580 \Omega \mathrm{m}$ to $950 \Omega \mathrm{m}$ (Fig. 4 and 7). The result indicates that the soil around VES 2 and VES 5 are devoid of organic matter that gives nutrients for plants growth. The resistivity results of the soil layers across the study area show that the soil has good load bearing capacity to carry load such as tractors, farm tools and implements, without soil failure. The inversion model for the VES results also shows that the ground water table across the area ranged from $60 \mathrm{~m}$ to $290 \mathrm{~m}$. The shallow depths occur around AAU dam while the deep depths are distributed across the central to the north-east of the study area as shown in Fig. 2. The water table depths across the area shows that their won't be excessive influx of groundwater to the surface during the peak of raining season. 


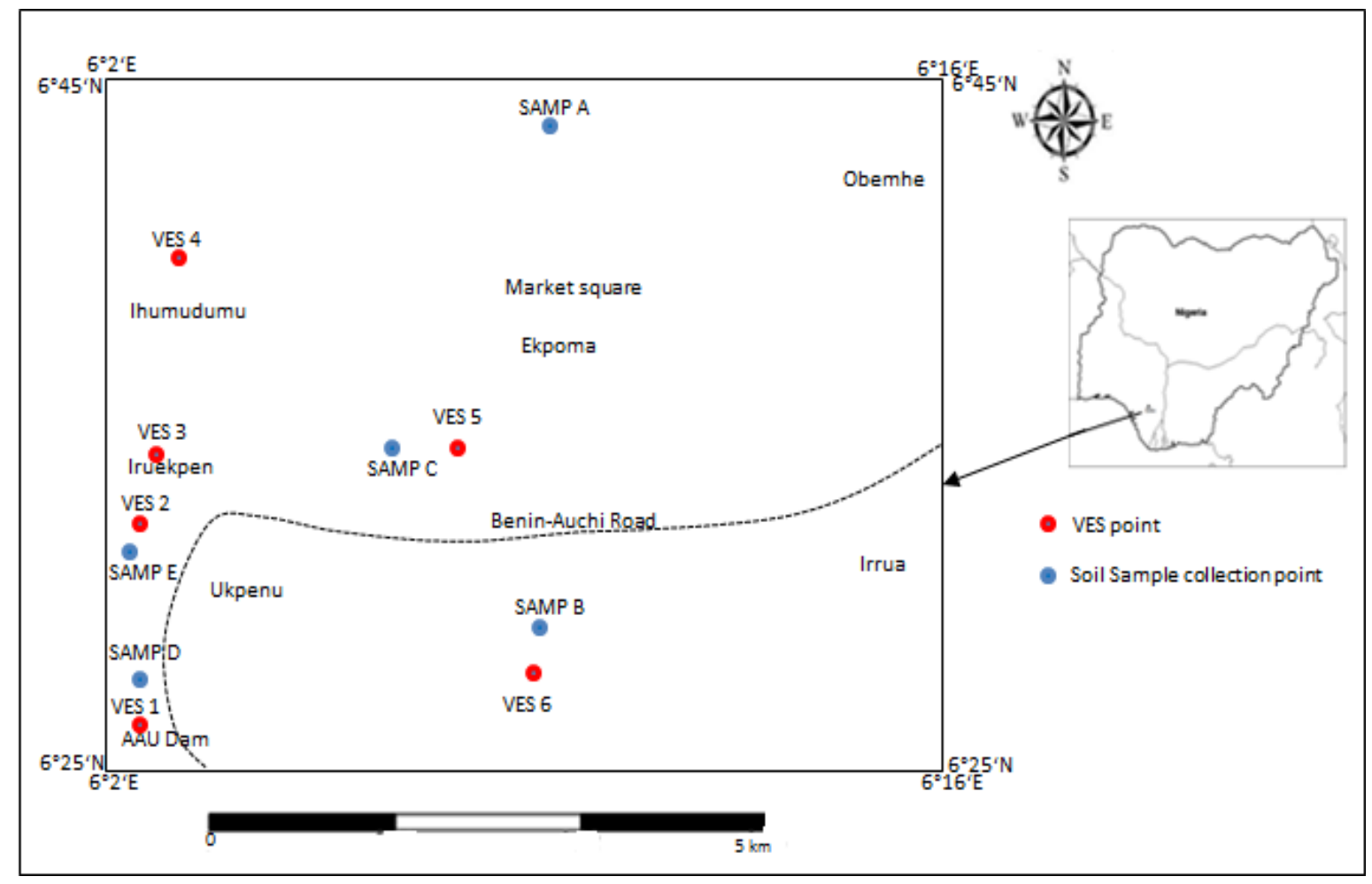

Fig. 2. Map showing soil sample collection points and VES points across the study area

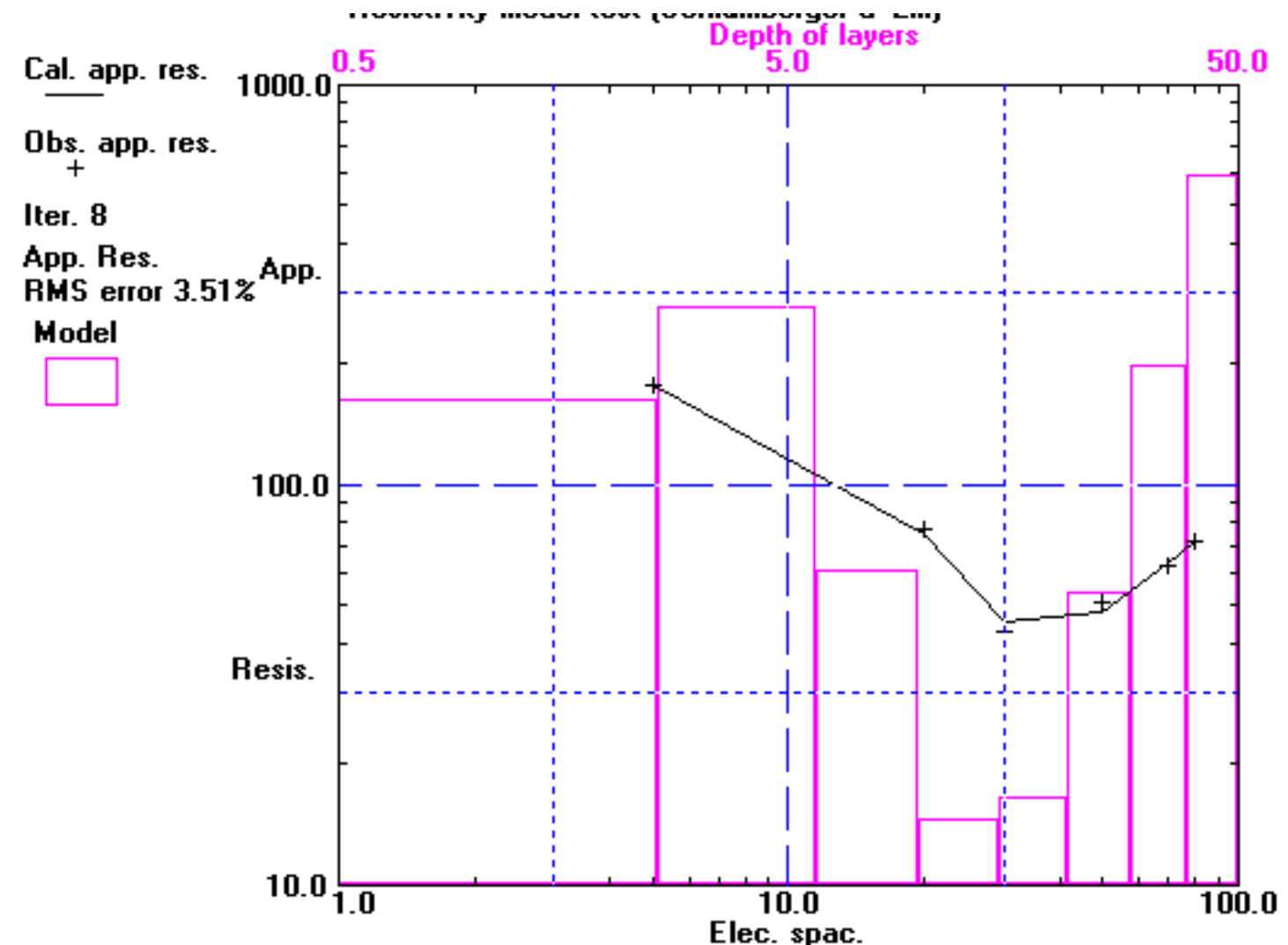

Fig. 3. Inverted model layer for VES 1 : Ukpenu-Ibhiese and Iruekpen Edo State 


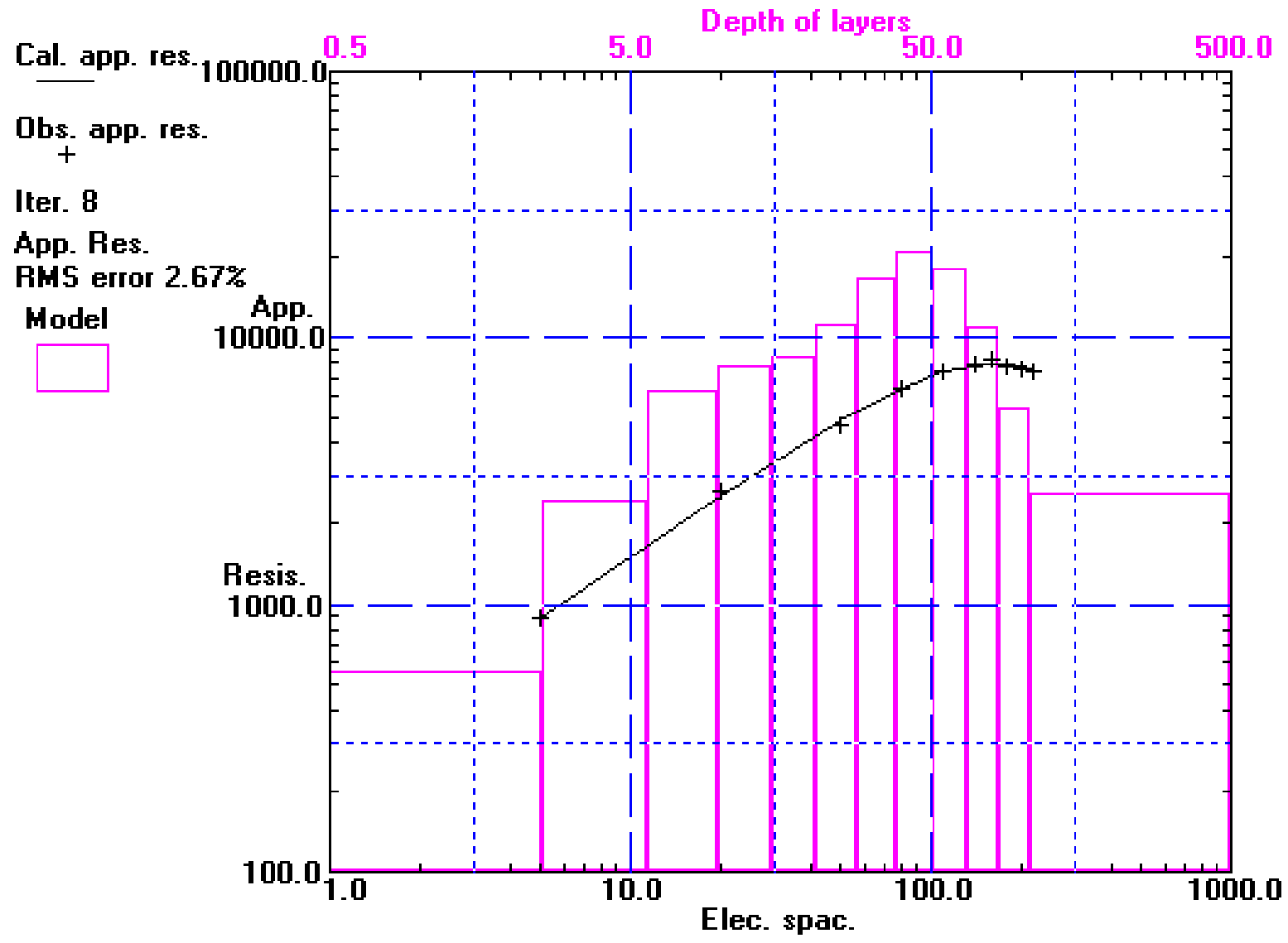

Fig. 4. Inverted model layer for VES 2: Ukpenu-Ibhiese and Iruekpen Edo State

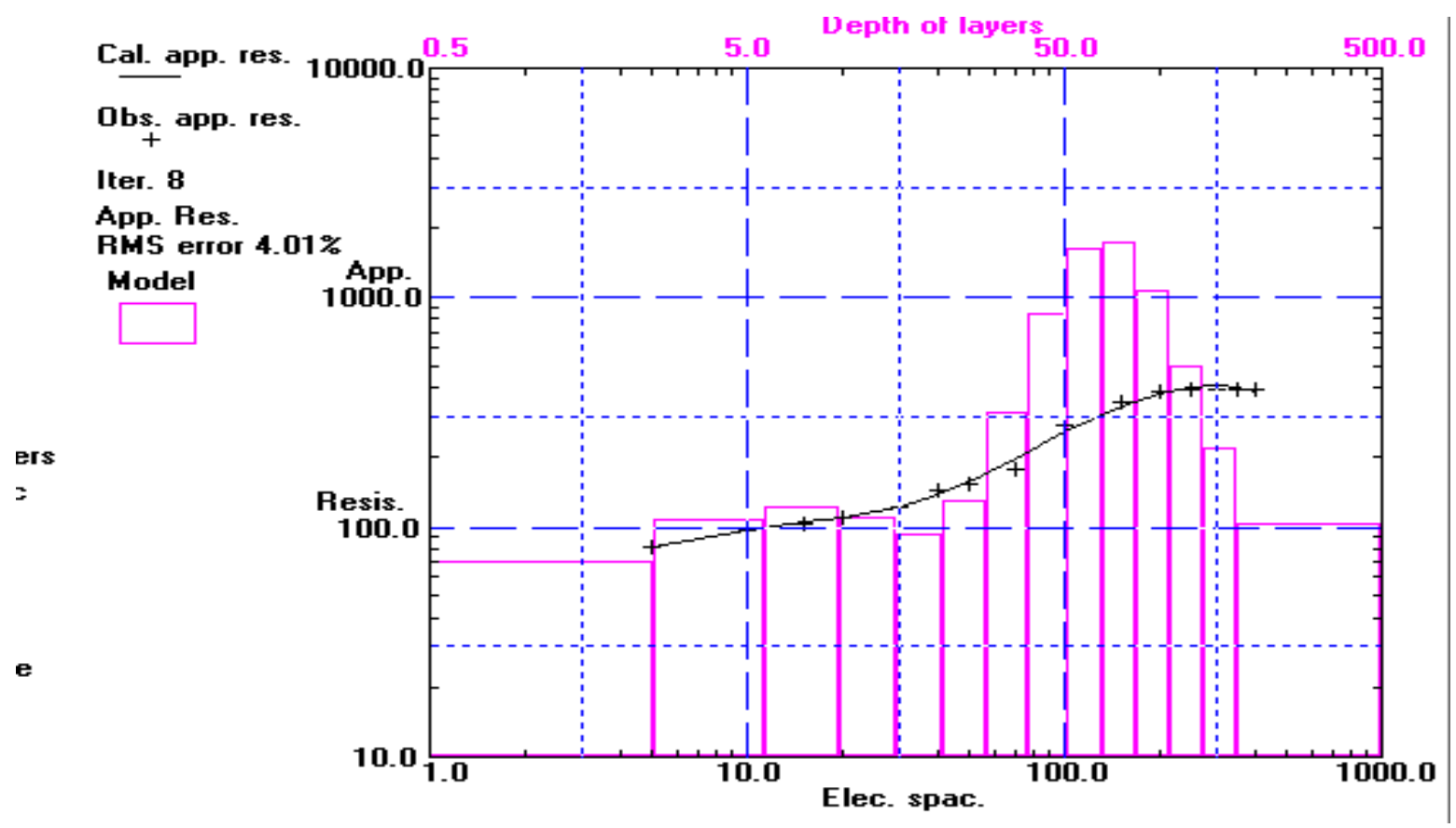

Fig. 5. Inverted model layer for VES 3: Ukpenu-lbhiese and Iruekpen Edo State 


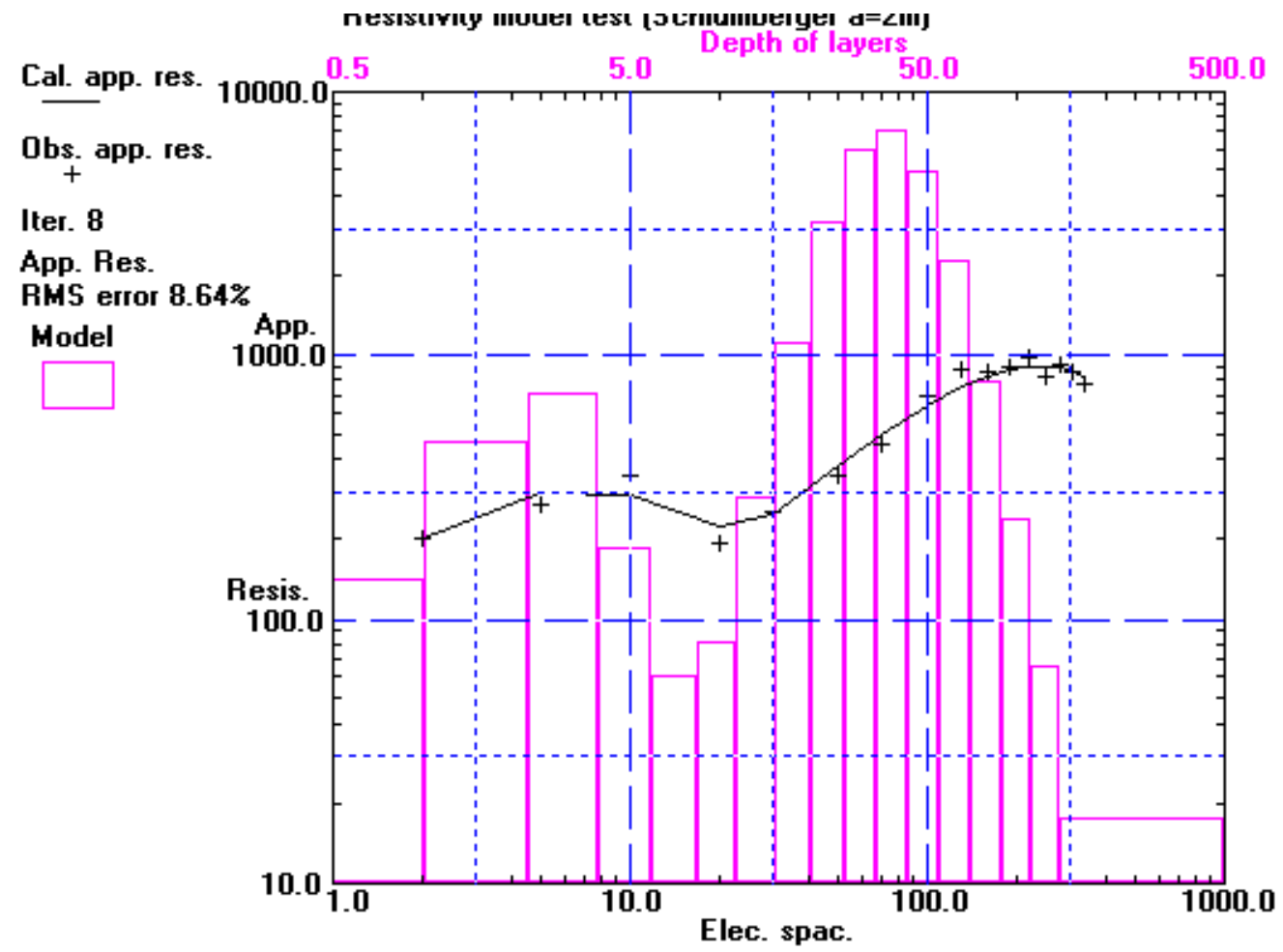

Fig. 6. Inverted model layer for VES 4 : Ukpenu-Ibhiese and Iruekpen Edo State

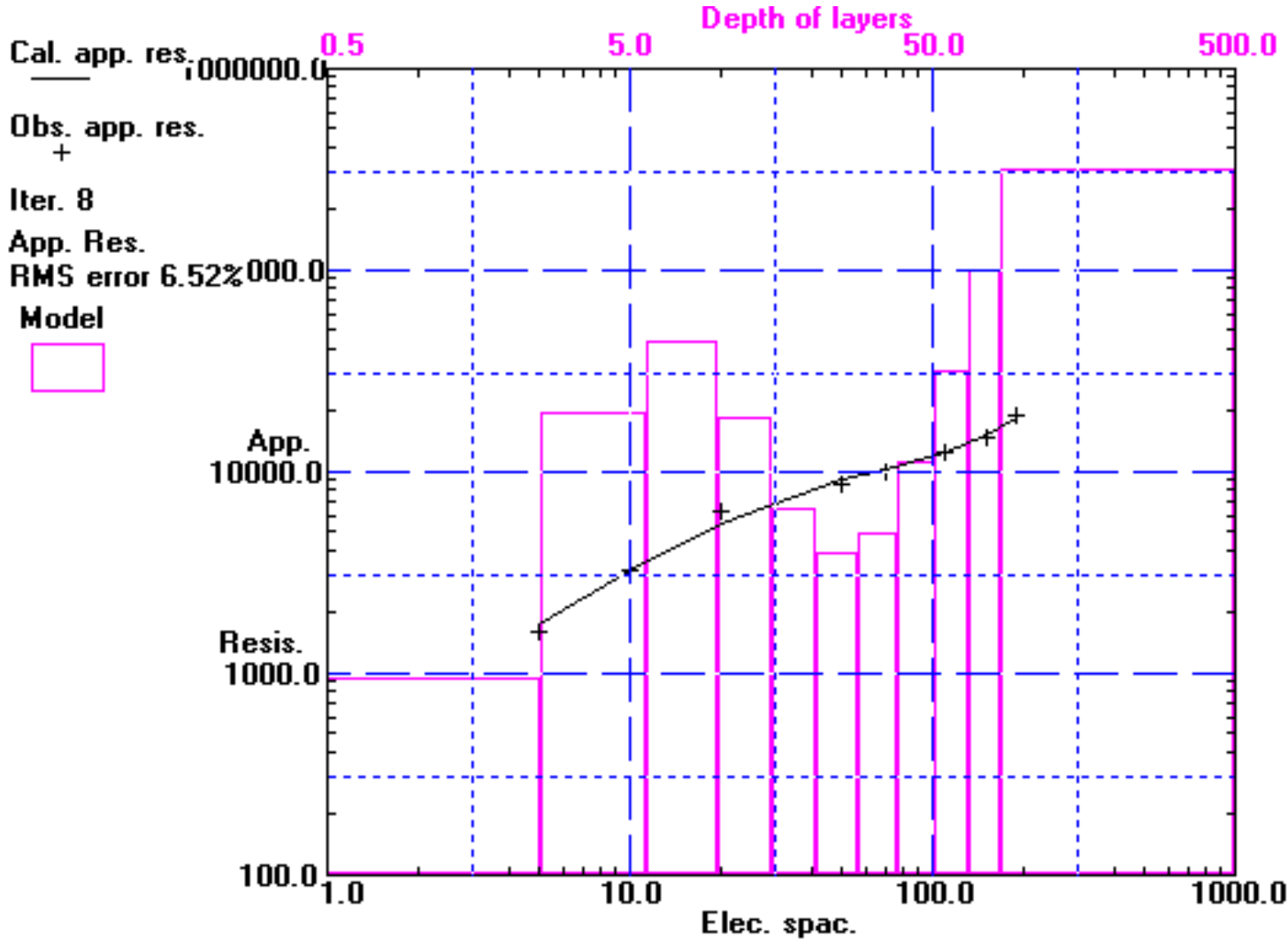

Fig. 7. Inverted model layer for VES 5 : Ukpenu-Ibhiese and Iruekpen Edo State 


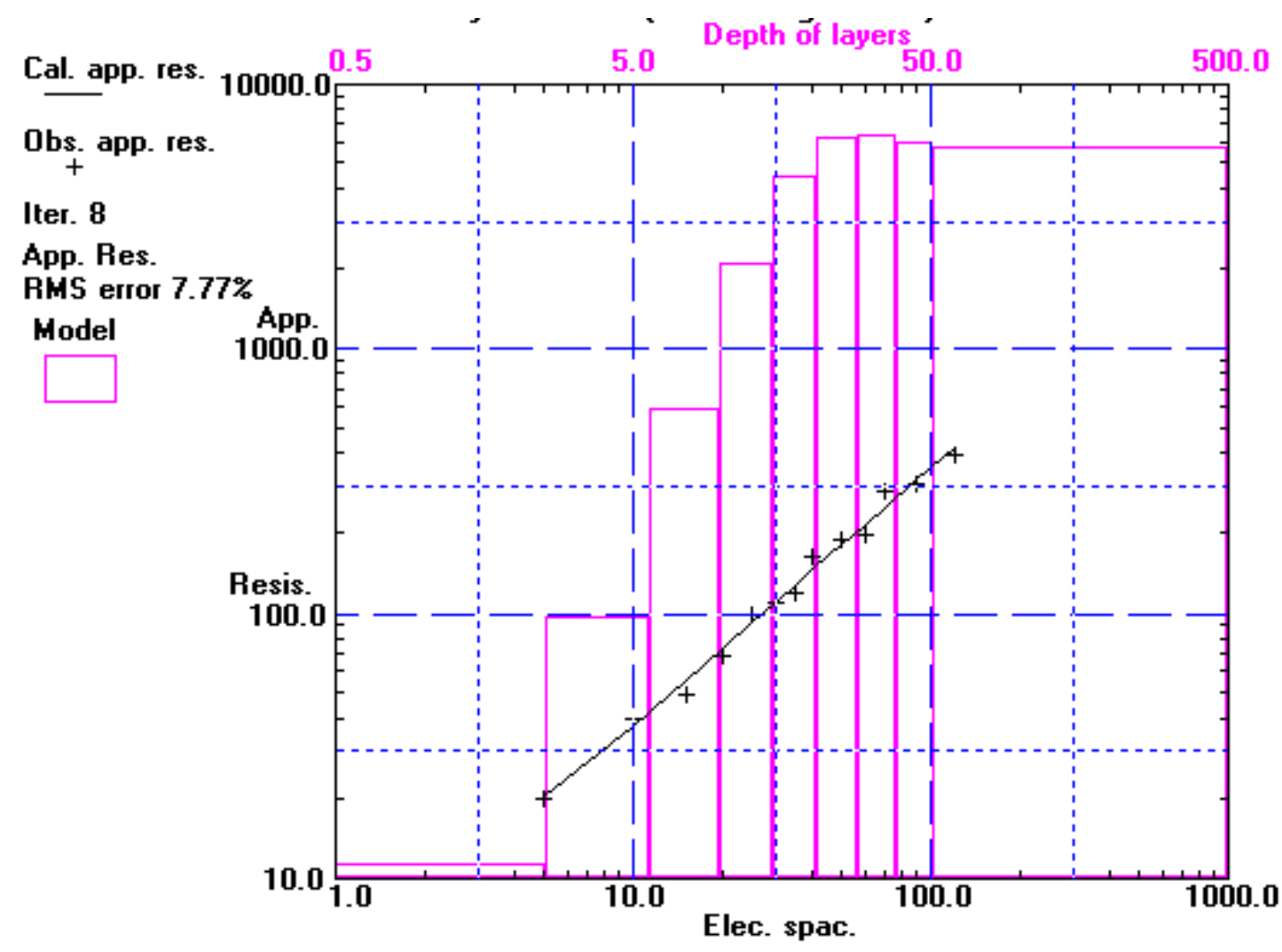

Fig. 8. Inverted model layer for VES 6: Ukpenu-lbhiese and Iruekpen Edo State

Table 1. Result of apparent resistivity data obtained from the study area

\begin{tabular}{lllllllll}
\hline $\mathbf{S} / \mathbf{N}$ & $\mathbf{A B} / \mathbf{2}$ & $\mathbf{M N} / \mathbf{2}$ & $\begin{array}{c}\text { VES1 } \\
\mathbf{( \Omega m})\end{array}$ & $\begin{array}{l}\text { VES2 } \\
(\mathbf{\Omega m})\end{array}$ & $\begin{array}{l}\text { VES3 } \\
(\mathbf{\Omega m})\end{array}$ & $\begin{array}{l}\text { VES4 } \\
(\mathbf{\Omega m})\end{array}$ & $\begin{array}{l}\text { VES5 } \\
(\mathbf{\Omega m})\end{array}$ & $\begin{array}{l}\text { VES6 } \\
(\mathbf{\Omega m})\end{array}$ \\
\hline $\mathbf{1}$ & 5.0 & 2.0 & 2243 & 4109 & 234 & 2357 & 5623 & 3234 \\
$\mathbf{2}$ & 20.0 & 2.0 & 2700 & 9052 & 241 & 2257 & 2138 & 2345 \\
$\mathbf{3}$ & 50.0 & 5.0 & 306 & 775 & 150 & 2669 & 2145 & 3456 \\
$\mathbf{4}$ & 80.0 & 5.0 & 320 & 968 & 156 & 3454 & 2160 & 3678 \\
$\mathbf{5}$ & 110.0 & 10.0 & 326 & 128 & 120 & 3821 & 3202 & 3890 \\
$\mathbf{6}$ & 140.0 & 10.0 & 369 & 142 & 90 & 3892 & 3262 & 4567 \\
$\mathbf{7}$ & 160.0 & 15.0 & 365 & 120 & 80 & 3872 & 3254 & 4789 \\
$\mathbf{8}$ & 180.0 & 15.0 & 343 & 80 & 76 & 3861 & 2360 & 4678 \\
$\mathbf{9}$ & 220.0 & 20.0 & 154 & 78 & 70 & 3880 & 1345 & 5678 \\
$\mathbf{1 0}$ & 250.0 & 20.0 & 132 & 67 & 50 & 2091 & 1234 & 6816 \\
\hline
\end{tabular}

The result of soil test analysis showed that the soil $\mathrm{pH}$ ranged from 6.2 to 7.2 (Table 2) across the study area which indicates suitable soil for agricultural purpose. The organic matter percentage of the soil across the study area ranged from $5 \%$ to $8.21 \%$ (Table 2) with the highest organic matter occurring in the south west to the north west of the study area. This result is in conformity with that of VES results acquired in the study area. Sample A and C gave the least organic matter contents in the area, ranged from $5 \%$ t0 $6.75 \%$ (Table 2). This indicates that soil around the area where soil sample $\mathrm{A}$ and $\mathrm{C}$ were obtained has low organic matter. This symbolizes that the area has low crop nutrients which is similar to VES result that showed resistivity values ranged from $580 \Omega \mathrm{m}$ to $950 \Omega \mathrm{m}$. Similarly, in the areas where these values of resistivity were observed, the nitrogen, phosphorus, and potassium contents are general low compare to other parts of the study area. Nitrogen content of the soil ranged from $61.1 \%$ to $62.2 \%$, Phosphorus content of the soil ranged from $50 \mathrm{mg} / \mathrm{kg}$ to $54 \mathrm{mg} / \mathrm{kg}$, and Potassium content of the soil ranged from 205.3 $\mathrm{k}(\mathrm{colmol} / \mathrm{kg})$ to $299 \mathrm{k}(\mathrm{colmol} / \mathrm{kg})$ while in the 
other parts of the study, southwest to northwest has higher values. This spatial distributions of soil nutrient in the study area shows that southwest to northwest is rich in soil nutrient for crop growth according to Standard soil test nutrient classification of Kryzanowski et al. (1988) s shown in Table 4. This result confirms the resistivity result of the study area that southwest to northwest is very rich in essential soil nutrient necessary for plant's growth (Fig. 9Fig. 11).

The soil grain analysis (Textural) showed that silt is the dominants grain ranges from $71 \%$ to Over $80 \%$ (Table 3). Clay has the second highest percentage after silt, it ranges from $10.3 \%$ to $13.8 \%$ while sand is the least (Fig. 12)

Table 2. Results of soil test in Ukpenu -Ibhiese and Iruekpen, Ekpoma

\begin{tabular}{|c|c|c|c|c|c|}
\hline Soil Parameters & Sample A & Sample B & Sample C & Sample D & Sample E \\
\hline pH & 6.2 & 6.43 & 7.1 & 7.1 & 6.62 \\
\hline Organic matter (\%) & 5 & 7.37 & 6.75 & 7.16 & 8.21 \\
\hline Total Nitrogen (\%) & 62.20 & 72.11 & 61.10 & 74.00 & 69.20 \\
\hline Phosphorus (mg/kg) & 54.22 & 64.23 & 50.14 & 71.00 & 65.02 \\
\hline Mg/kgExch acidity & 0.5 & 0.4 & 0.4 & 0.4 & 0.4 \\
\hline $\mathrm{Ca}(\mathrm{mg} / \mathrm{kg})$ & 3.61 & 3.44 & 5.63 & 4.08 & 1.24 \\
\hline$M g(\mathrm{mg} / \mathrm{kg})$ & 1.16 & 1.15 & 1.32 & 1.14 & 2.59 \\
\hline $\mathrm{K}(\mathrm{cmol} / \mathrm{kg})$ & 299.0 & 402.0 & 205.3 & 400.3 & 397.2 \\
\hline $\mathrm{Na}(\mathrm{mg} / \mathrm{kg})$ & 2.02 & 1.01 & 2.96 & 2.92 & 3.97 \\
\hline$M n(\mathrm{mg} / \mathrm{kg})$ & 4.2 & 4.72 & 14.75 & 1.83 & 42.87 \\
\hline $\mathrm{Fe}(\mathrm{mg} / \mathrm{kg})$ & 21.53 & 21.48 & 20.17 & 27.1 & 61.5 \\
\hline $\mathrm{Cu}(\mathrm{mg} / \mathrm{kg})$ & 1.92 & 1.63 & 2.07 & 1.93 & 1.78 \\
\hline $\mathrm{Zn}(\mathrm{mg} / \mathrm{kg})$ & 1.19 & 0.84 & 1.09 & 0.82 & 4.2 \\
\hline
\end{tabular}

Table 3. Results of soil particle size analysis

\begin{tabular}{llll}
\hline Samples & Silt (\%) & Sand (\%) & Clay $(\%$ \\
\hline A & 81.2 & 8.5 & 10.3 \\
B & 81.4 & 6.7 & 11.5 \\
C & 73.8 & 10.3 & 15.8 \\
D & 76 & 8.5 & 15.5 \\
E & 80.4 & 6.8 & 12.8 \\
\hline
\end{tabular}

Table 4. Standard soil test nutrient classification (after Kryzanowski et al., 1988)

\begin{tabular}{|c|c|c|c|c|c|c|c|c|c|c|}
\hline \multirow{2}{*}{ Soil Test Nutrient } & \multirow{2}{*}{$\begin{array}{l}\text { Depth, } \\
\text { cm (in) }\end{array}$} & \multicolumn{9}{|c|}{ Classification' } \\
\hline & & \multicolumn{3}{|c|}{ Deficient $^{2}$} & \multicolumn{3}{|c|}{ Marginal } & \multicolumn{3}{|c|}{ Adequate } \\
\hline Nitrate-Nitrogen (Dryland) (lb/ac) & $\begin{array}{l}0-60 \mathrm{~cm} \\
(0-24 \mathrm{in})\end{array}$ & $<11$ & $11-20$ & $21-30$ & $31-40$ & $41-50$ & $51-60$ & $61-70$ & $71-80$ & $>80$ \\
\hline Nitrate-Nitrogen (Irigated) (lb/ac) & $\begin{array}{l}0-60 \mathrm{~cm} \\
(0-24 \mathrm{in})\end{array}$ & $<21$ & $21-40$ & $41-60$ & $61-80$ & $81-100$ & $101-120$ & $121-140$ & $141-160$ & $>160$ \\
\hline Phosphorus (lb/ac) & $\begin{array}{l}0-15 \mathrm{~cm} \\
(0-6 \mathrm{in})\end{array}$ & $<11$ & $11-20$ & $21-25$ & $26-30$ & $31-40$ & $41-50$ & $51-70$ & $71-90$ & $>90$ \\
\hline Potassium (lb/ac) & $\begin{array}{l}0-15 \mathrm{~cm} \\
(0-6 \mathrm{in})\end{array}$ & $<51$ & $51-100$ & $101-150$ & $151-200$ & $201-250$ & $251-300$ & $301-400$ & $401-600$ & $>600$ \\
\hline Sulphur (lb/ac) & $\begin{array}{l}0-60 \mathrm{~cm} \\
(0-24 \mathrm{in})\end{array}$ & $<6$ & $6-10$ & $11-15$ & $16-20$ & $21-25$ & $26-30$ & $31-40$ & $41-50$ & $>50$ \\
\hline Copper (ppm) & $\begin{array}{l}0-15 \mathrm{~cm} \\
(0-6 \mathrm{in})\end{array}$ & & $<0.5$ & & & $0.5-1.0$ & & & $>1.0$ & \\
\hline Manganese (ppm) & $\begin{array}{l}0-15 \mathrm{~cm} \\
(0-6 \mathrm{in})\end{array}$ & & $<1.0$ & & & $1.0-2.0$ & & & $>2.0$ & \\
\hline Iron (ppm) & $\begin{array}{l}0-15 \mathrm{~cm} \\
(0-6 \mathrm{in})\end{array}$ & & $<2.0$ & & & $2.0-4.0$ & & & $>4.0$ & \\
\hline Zinc (ppm) & $\begin{array}{l}0-15 \mathrm{~cm} \\
(0-6 \mathrm{in})\end{array}$ & & $<0.5$ & & & $0.5-1.0$ & & & $>1.0$ & \\
\hline Boron' (ppm) & $\begin{array}{l}0-15 \mathrm{~cm} \\
(0-6 \mathrm{in})\end{array}$ & & $<0.35$ & & & $0.35-0.50$ & & & $0.50-3.50$ & \\
\hline Chloride (ppm) & $\begin{array}{l}0-15 \mathrm{~cm} \\
(0-6 \mathrm{in})\end{array}$ & & $<15.0$ & & & $16-30$ & & & $>30$ & \\
\hline
\end{tabular}




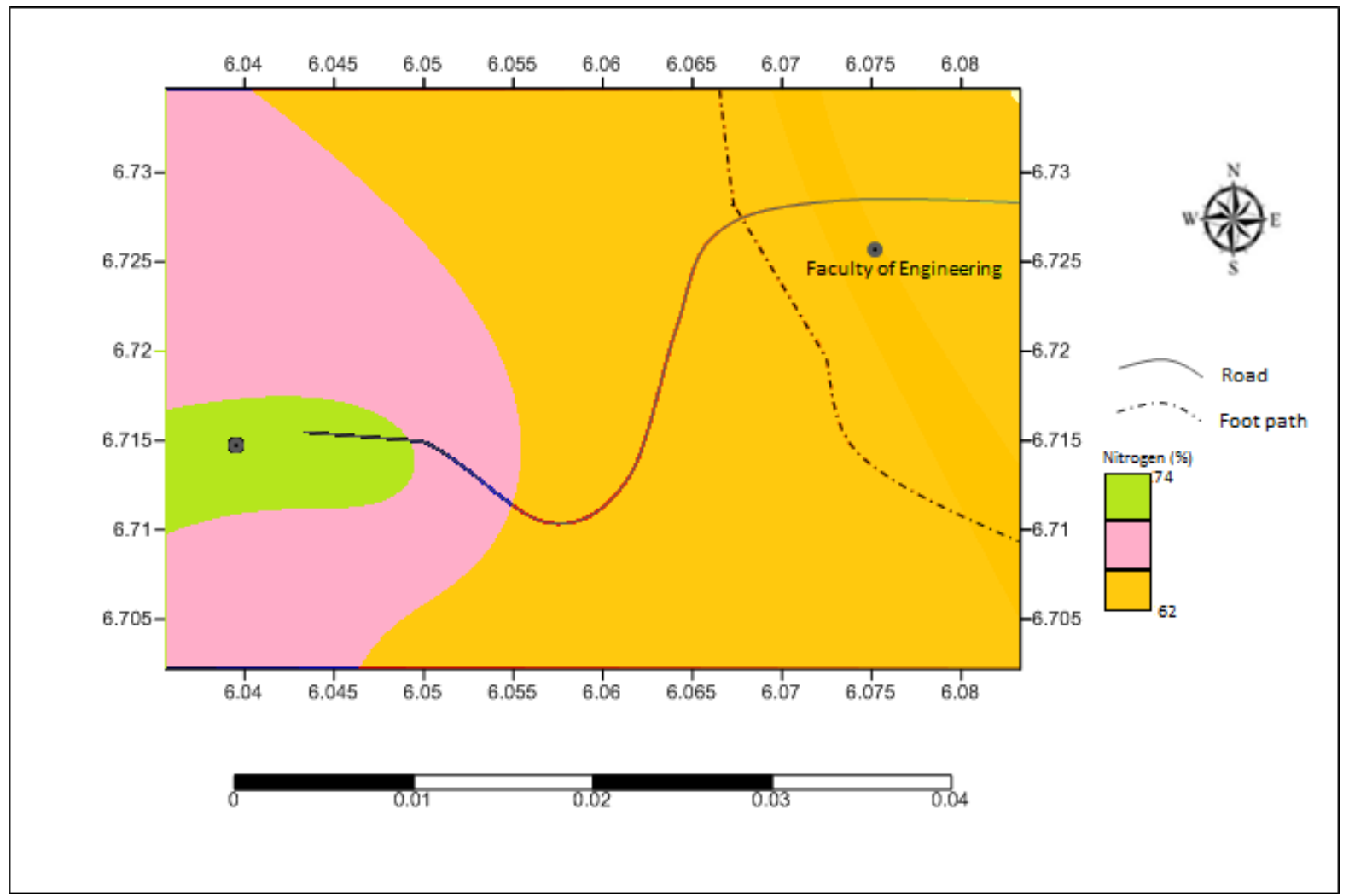

Fig. 9. Map showing percentage spatial concentration of Nitrogen across the study area

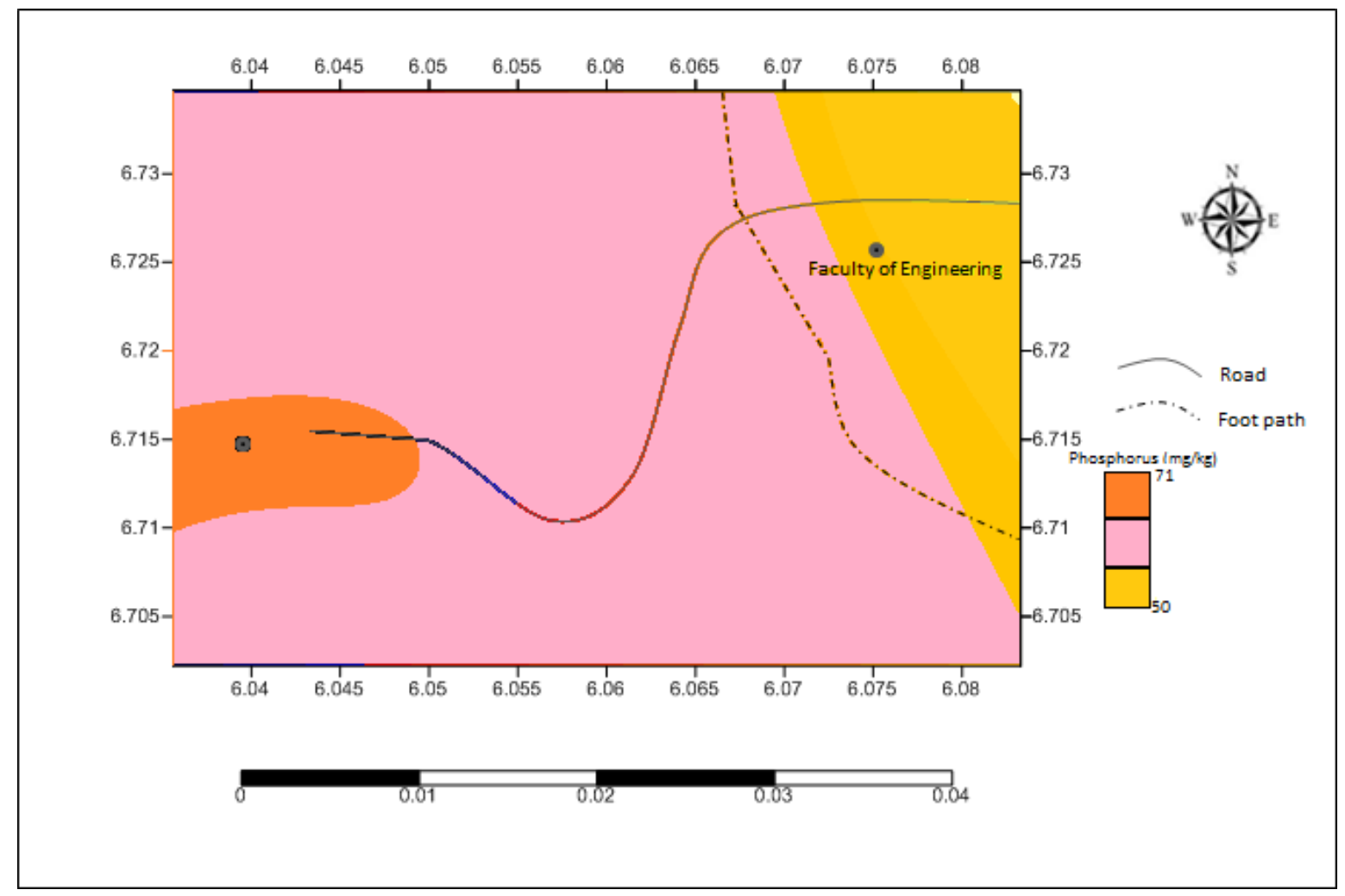

Fig. 10. Map showing percentage spatial concentration of Phosphorus across the study area 


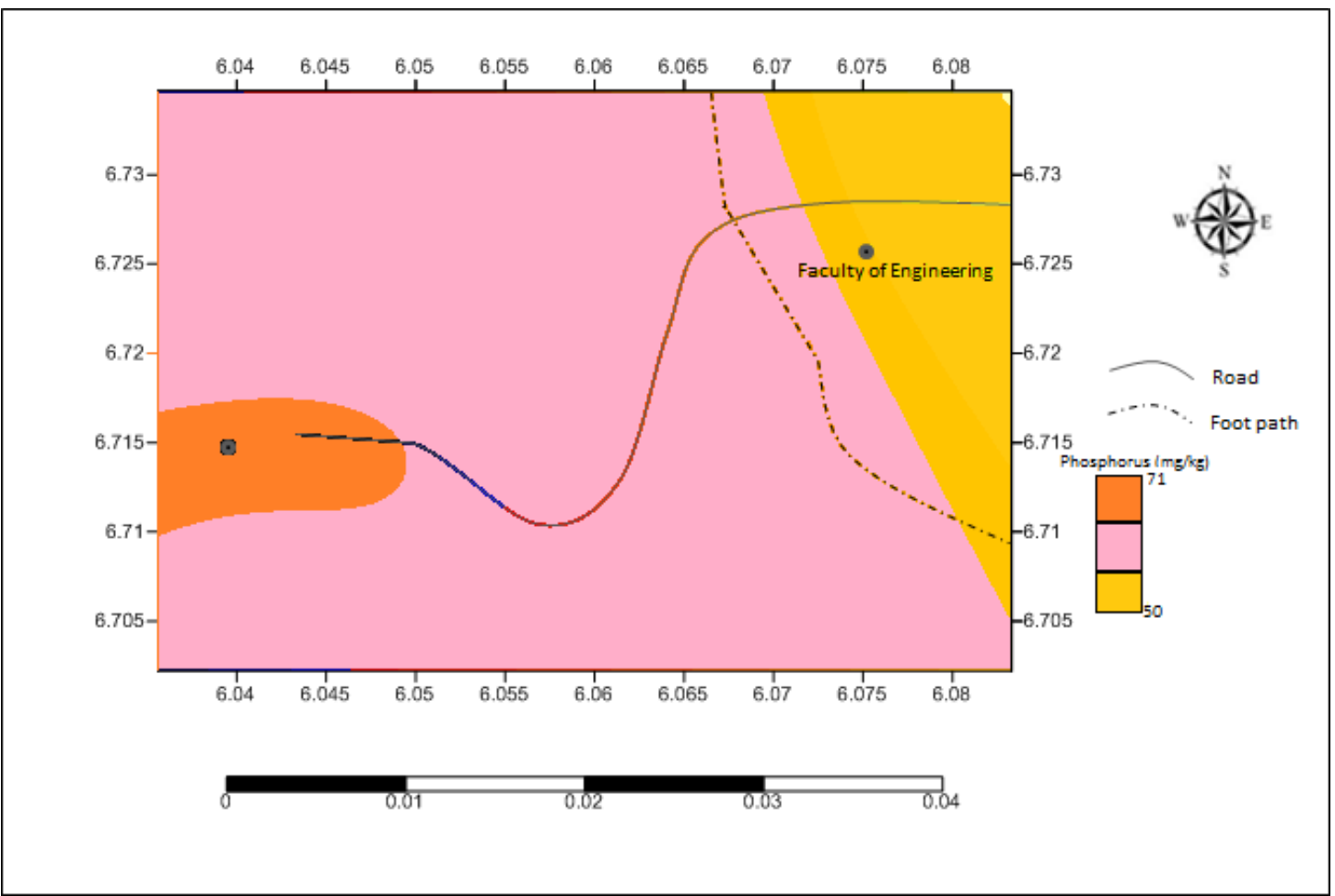

Fig. 11. Map showing percentage spatial concentration of Potassium across the study area

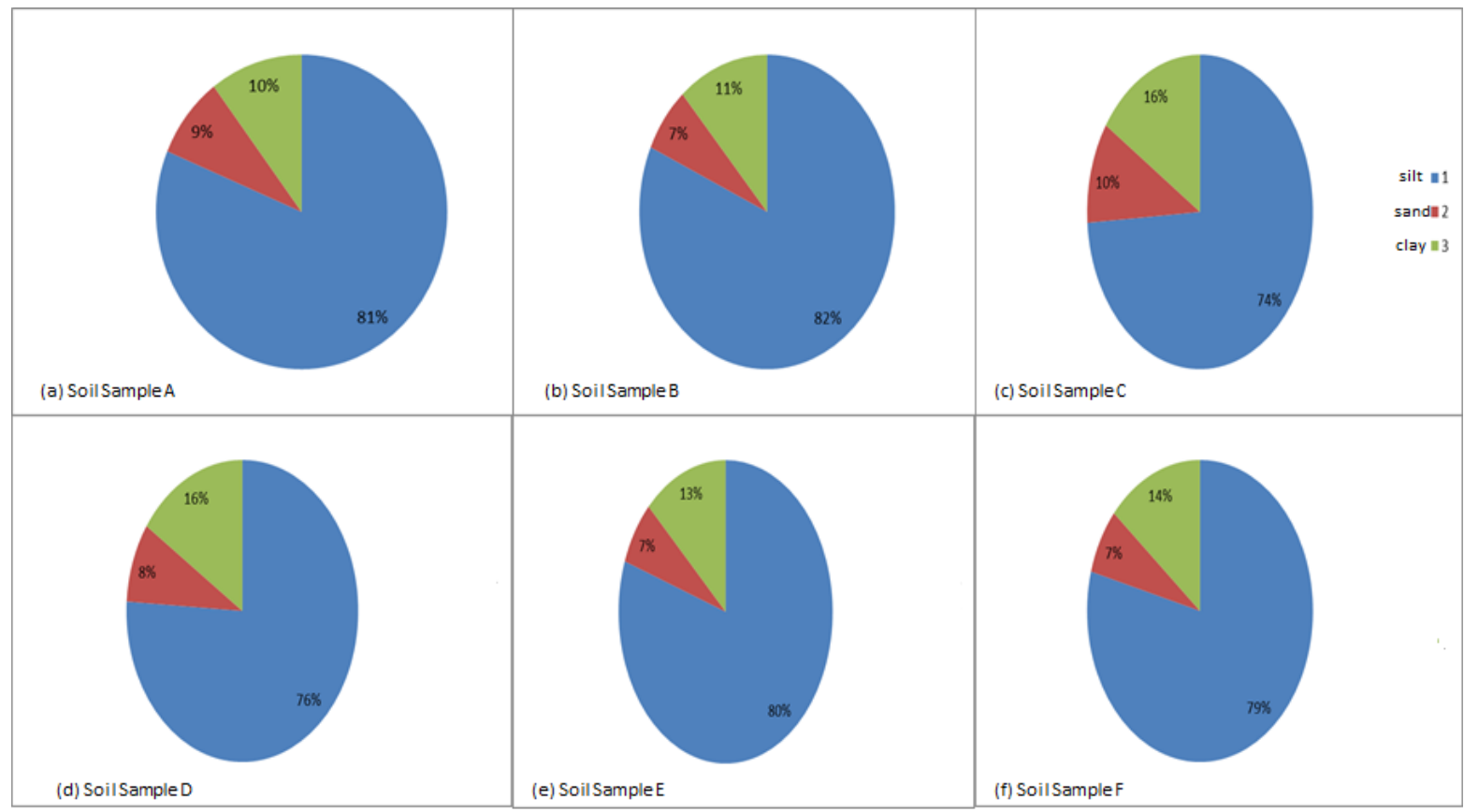

Fig. 12. Map showing percentage of sand, clay and silt across the collection point in the study area

\section{CONCLUSION}

Electrical geophysical method has been applied and its result compared to conventional soil test analysis in this study, to select area with viable soil nutrients for the purpose of crop cultivation. The result has shown good conformity. The results from the Geophysical ,Soil test and soil 
grain size analysis, proved that soil physical properties thus detected and mapped can be used as a proxy of physical, chemical, and biological features relevant for the management of soils, based on their behavior, spatial variability, and time dynamics in the area of study. However, electrical geophysical method has advantage of information about bearing load capacity of the soil, water content, soil in-situ information, and depth to water table over the conventional soil test. Hence, site selection study for agricultural purposes should be done by integrating electrical geophysical method with soil test analysis for adequate and reliable result. Since the result of the soil test analysis has showed that the soil in southwest and the northwest area of the study area is rich in NPK and other soil nutrients needed for crop growth in require proportion hence we recommend that the area should be used for agricultural purposes.

\section{COMPETING INTERESTS}

Authors have declared that no competing interests exist.

\section{REFERENCES}

1. Sheriff. Sheriff RE. Encyclopedic dictionary of exploration geophysics, 3rd edn. Society of Exploration Geophysicists, Tulsa. 1991;2002.

2. Corwin DL, Lesch SM.Apparent soil electrical conductivity measurements in agriculture. Comput Electron Agric. 2005;46:11-43.

3. Reza SK. Soil fertility index, soil evaluation factor, and microbial indices under different land uses in acidic soil of Humid Subtropical India,Olympus; 2010.

4. Samouelian A, Cousin I, Richard G, Tabbagh A, Bruand A.Electrical resistivity imaging for detecting soil cracking at the centimetric scale. Soil Sci Soc Am J. 2003; 67:1319-1326.

5. Dexter AR.Soil friability: Theory, measurement and the effects of management and organic carbon content,European Journal of Soil Science; 1988.

6. Adviento-Borbe MAA, Doran JW, Drijber RA, Dobermann A. Soil electrical conductivity and water content affect nitrous oxide and carbon dioxide emissions in intensively managed soils. Journal of Environmental Quality. 2006;35:19992010.

7. Edlefsen NE, Anderson AB.The fourelectrode resistance method for measuring soil-moisture content under field conditions. Soil Sci 51:367-376. Halvorson and Rhodes. 1941; 1974.

8. KirkhamD, Taylor GS. Some tests of a four-electrode probe for soil moisture measurements. Soil Sci. Soc. Proc. 1949;14:42-46.

9. McCorkle WH. Determination of soil moisture by the method of multiple electrodes.Tex. Agr. Exp. Sta. 1931;Bul.426.

10. Corwin DL, Plant RE. Applications of apparent soil electrical conductivity in precision agriculture. Comput, Electron Agric.2005;46:1-10.

11. Zdanov MS, Keller GV. The geoelectrical methods in geophysical exploration. Methods in geochemistry and geophysics. Series. Elsevier. Amsterdam-London-New York-Tokyo. 1994;31.

12. Salufu SO, Ujuanbi O. The geology and structural geology of Ekpoma And Irrua: Implication for The Hydrology And Hydrogeologic Setting of The Areas. Nigerian Annals of Natural Sciences. 2015; 15:131-138.

(c) 2021/saac and Samuel; This is an Open Access article distributed under the terms of the Creative Commons Attribution License (http://creativecommons.org/licenses/by/4.0), which permits unrestricted use, distribution, and reproduction in any medium, provided the original work is properly cited. http://www.sdiarticle4.com/review-history/67523 